\title{
THE EFFECTS OF DIFFERENT LITTER MATERIAL ON BROILER PERFORMANCE AND FEET HEALTH
}

\author{
Nchele KULEILE ${ }^{\star 凶}$, Itumeleng METSING, Calelane TJALA, Teboho JOBO and Mamajone PHORORO \\ Department of Animal Science, National University of Lesotho, Roma 180, Lesotho \\ Email: nchelekuleile@gmail.com \\ Supporting Information
}

\begin{abstract}
The study was implemented at the National University of Lesotho with the aim to find a potential litter material for use in broiler production. The study followed a completely randomized design with four litter treatments replicated three times. A well ventilated house divided into 12 pans was used where each pan or a replicate contain 15 birds with a total of $(n=180)$ birds. Feeding and watering were done on ad libitum basis while the normal routine for broiler production was followed. Litter treatments were made up of control represented by wood shaving and it was compared to dried pine leaves, decomposed kraal manure and sand. All litter materials were applied at the depth of $10 \mathrm{~cm}$. Data was collected on the following parameters broiler production, feet health and chemical and physical properties. Litter material treatment had no significant influence on feed intake, body weight, body weight gain, and feed conversion ratio and mortality rate. Regarding broiler feet health litter treatment had significant influence on foot pad dermatitis while hock burns and broiler temperature were not statistically different amongst litter treatments. Litter evaluation results revealed that different litter sources were differing significantly in terms ammonia emissions, water holding capacity. pH and bulk density while litter temperature did not differ significantly between litter treatments. It was concluded that both dried pine leave and decomposed kraal manure are potential sources that could replace wood shavings in broiler production. Dried pine leaves ideal for improved production while decomposed kraal manure deemed fit for ensure good feet health. It is therefore recommended that farmers in Lesotho can use both decomposed kraal manure and dried pine leaves to replace wood shavings.
\end{abstract}

Keywords: Feet health, Kraal manure, Lesotho, Litter material, Wood shaving.

\section{INTRODUCTION}

Litter quality is of great importance to the welfare of broiler chicken, as they generally spend their entire life in contact with litter (Lonkar, et al., 2018 and Kryeziu et al., 2018). Litter serves several functions that include thermal insulation, moisture absorption, protective barrier from the ground, and it also allows for natural scratching behavior. The quality of the in-house environment is highly dependent upon litter quality (Rizt et al., 2017). An effective bedding material must be readily available, absorbent, lightweight, inexpensive and non-toxic (Rizt et al., 2009; Waziri, Kaltungo, 2017 and Munir et al., 2019). The litter environment is ideal for bacterial proliferation and ammonia production. The two factors that influence litter conditions most are manure and moisture. The ideal litter material should have a moisture content of 2025\%, a pH of 8-10, and ammonia content should not exceed 25 ppm (Dunlop et al., 2016 and Gençoğlan and Gençoğlan, 2017). Excess moisture in the litter increases the incidence of breast blisters, skin bums, scabby areas, bruising, condemnations and downgrades (Hossain et al., 2018). Wet litter is the primary cause of ammonia emissions, one of the most serious performance and environmental factors affecting broiler production today (Rizt et al., 2017). Controlling litter moisture is the most important step in avoiding ammonia problems.

Pine shavings and saw dust have been the most preferred litter source for broilers in Lesotho but because of the high demands, their prices and availability is now a big problem for farmers. In turn farmers are forced to use alternative bedding materials such as dry grass, undecomposed kraal manure and shredded paper characterized by low moisture holding capacity and this results in fungal growth which causes many diseases, increased mortality and welfare concerns in the form of foot pad dermatitis (FPD). Contact dermatitis affects skin surfaces that have prolonged contact with wet litter or other wet flooring surfaces. The condition is manifested as blackened skin progressing to erosions and fibrosis on the lower surface of the footpad, at the back of the hocks, and sometimes in the breast area (World Organization for Animal Health, 2018). If severe, the foot and hock lesions may contribute to lameness and lead to secondary infections (Shepherd et al., 2017). Animal welfare audits in Europe often use foot, hock, and breast burn-lesions as an indicator of housing conditions and the general welfare of the birds (Haslam et al., 2007). Therefore, the aim of this study is to evaluate alternative bedding materials that are inexpensive but had the potential to give comparable results to those of wood shavings under Lesotho condition. 


\section{MATERIALS AND METHODS}

\section{Ethical approval}

The scientific and ethics committee of the Faculty of Agriculture, National University of Lesotho approved the study protocol.

\section{Study area}

The study was carried out at the National University of Lesotho, Faculty of Agriculture farm in Roma some 34 kilometers southeast of Maseru, the capital of Lesotho. The Roma valley is broad and is surrounded by a barrier of rugged mountains which provide magnificent scenery. The university enjoys a temperate climate with four distinct seasons.

\section{Experimental Design}

Completely randomized design was used whereby four different sources of litter materials were used as treatments and replicated three times. Wood shavings was considered as the control, while, decomposed kraal manure, sand and dry pine tree leaves were considered as treatments 1, 2 and 3 respectively. Bedding material was laid at the depth of $10 \mathrm{~cm}$. On daily basis, patches of bedding that were too wet as a result of spills from the drinkers were removed from the pans and at end of every week bedding was raked to reduce the caking effect and also to allow air circulation.

\section{Birds and Management}

One hundred and eighty $(n=180)$ Ross 308 broiler chickens were reared under deep litter system. Before the arrival of chicks, the house was cleaned thoroughly and disinfected to kill the micro-organisms that might harm the chicks. All the birds were brooded together using a standard bedding material which is wood shavings for the first two weeks and then at the start of growing period, they were randomly distributed into four bedding material treatments, each treatment replicated 3 times with 15 birds per replicate. Birds were provided with continuous light for 24 hours. The three phase feeding was used and the birds were each phase lasted for two weeks. Feeds and water were given ad libitum.

\section{Data collection}

Data was collected on daily basis on health related parameters and on weekly basis for production performance and physical and chemical assessment of different litter sources.

\section{Production}

Feed intake was determined as the difference between total feed supplied and leftovers on weekly basis. Feed conversion ratio was calculated as, feed intake $(\mathrm{kg}) /$ lives weight $(\mathrm{kg})$. The body weight was measured using a measuring spring balance scale. Growth rate was measured as the final weight minus initial weight divided by number of days.

Feed intake $=$ total feed supplied- total feed left

Feed conversion ratio $(F C R)=$ feed intake $(\mathrm{kg}) /$ live weight gained $(\mathrm{kg})$

Growth rate $=$ final weight-initial weight/ number of days

Average body weight=total body weight/number of birds

\section{Feet health parameters}

Data was collected on the following parameters: mortality rate, signs of illness due to litter material emissions, body temperatures, hock burns and footpad dermatitis. Body temperature was measured using the digital thermometer at the end of each week. The hock burn were scored in six birds per replicate at six weeks of age using a 3 point scoring system ( $0=$ no burns; 1 = mild burns and $2=$ severe burns). The hock burns were assigned to one of three score. The mean score of hock was calculated as the cumulative total of the lesion scores divided by the total number of birds examined. (Thomas et al., 2004) Footpad lesions were assessed by eye and scored according to the protocol of Berg (1998) at the end of every week as follows;

$>$ Class $0=$ lesions absent or minor

$>$ Class $1=$ medium or mild lesions

$>$ Class $2=$ severe lesions.

\section{Litter material assessment}

A number of laboratory tests were done to assess the quality of litter materials and they included dry matter content, pH, Bulk density, water holding capacity, water releasing capacity and ammonia emitted by litter material. Litter samples were collected at the beginning and at the end of every feeding phase from five locations within each pen and thoroughly mixed. Subsamples were submitted to the Animal Science Laboratory for chemical analysis. Chemical analysis was performed according to Brake et al. (1992) and AOAC International (1995) guidelines. Bulk density was expressed as the weight of 1 litre of as-is litter material. Litter moisture was measured after drying for $24 \mathrm{~h}$ at $105^{\circ} \mathrm{C}$. The $\mathrm{pH}$ was recorded using an electronic meter after 30grams of macerated litter were added to 250 milliliter of deionised water, agitated for 5 minutes, and suspended for 30 minutes. 
Water-holding capacity was determined as follows: Litter samples were dried until constant weight and 50grams of litter was placed in a $\mathbf{5 0 0}$ milliliter beaker, the beaker was filled with water and left to stand for $\mathbf{3 0}$ minutes, excess water was then drained for 3 minutes and the sample was weighed again; the percentage of water absorbed was calculated on a DM basis.

To determine the water-releasing capacity, each litter sample was placed in a 3-cm-deep pan; the pan was filled with water and allowed to stand for $\mathbf{3 0}$ minutes; after draining the excess water for $\mathbf{3}$ minutes, the litter sample was weighed, the pan was then weighed $\mathbf{5}$ and $\mathbf{2 4}$ hours after draining, moisture loss at each time point was expressed as a percentage of the initial wet weight of the sample.

Determination of NH3 emissions was based on the micro-diffusion method as follows: $100 \mathrm{~g}$ of fresh litter was weighed, placed in a 500-millilitre cylindrical flask, and leveled. A 50-millitre beaker containing $10 \mathrm{millilitre}$ of $2 \%$ ( $\mathrm{m} / \mathrm{v}$ ) boric acid was placed on top of the litter; the flask was closed and incubated for $20 \mathrm{~h}$ at $30^{\circ} \mathrm{C}$; the boric acid solution was then titrated against sulphuric acid $0.1 \mathrm{~N}$ with metal orange and bromocresol green; volatilized $\mathrm{NH} 3$ (in milligrams per 100 grams of litter) was calculated by multiplying the amount of sulphuric acid used (A) by its normality and the molecular weight of ammonia: $\mathrm{NH} 3=\mathrm{A} \times 0.1 \times 17$.

\section{Data analysis}

Data was analyzed using IBM SPSS version 20 (2011) package and data was subjected to Analysis of Variance (ANOVA) to determine the differences among different litter materials.

Statistical model used is as follows; $Y i j=\mu+B j+\epsilon_{i j}$

Where;

Yij =ith observation of $j$ th bedding material

$\mu=0$ verall mean (mean effect)

$\mathrm{Bj}=$ Effect due to bedding material

$€ \mathrm{ij}=$ Experimental or random error

\section{RESULTS AND DISCUSSIONS}

\section{Production parameters}

The litter material treatments had no significant $(P \geq 0.05)$ influence in all broiler production parameters such asfeed intake, feed conversion ratio, body weight, growth rate and mortality. However, with the comparison to the control, broilers that were reared on dry pine leaves had closest performance in terms of feed intake, feed conversion ratio, body weight, and growth rate. In terms of mortality decomposed kraal manure gave similar results to control.

The results of the current study are in agreement with the findings of Hafeez et al. (2009); Davis et al. (2010); Mendes et al. (2011); Villagra et al. (2011); van Harn et al. (2012); Bjedov et al. (2013); Taherparvar et al. (2016) and Shepherd et al. (2017) who reported that different litter material sources had no effect on feed intake, weight gain, efficiency of feed conversion and growth rate. On the other hand these results are in contrast with the results of Anonymous (1992); Asaniyan et al. (2007); Toghyani et al. (2010), and Lonkar et al. (2018) who reported that the litter material had a significant $(\mathrm{P} \leq 0.05)$ influence on body weight, body weight gain and feed conversion ratio. Based on feed intake and growth rate dried pine leaves were found to be the closest potential litter to wood shavings in terms of production performance.

Table 1 - The effects of litter material on broiler production

\begin{tabular}{|c|c|c|c|c|c|c|}
\hline \multirow{2}{*}{ Parameters } & \multicolumn{4}{|c|}{ Litter treatments } & \multicolumn{2}{|c|}{ Significance } \\
\hline & Control & T1 (DPL) & T2 (DKM) & T3 (SAND) & $\mathbf{P}^{1}$ & $\mathrm{CV}^{2}$ \\
\hline Feed intake (g/week) & 580 & 581 & 637 & 633 & 0.975 & 27.8 \\
\hline FCR $^{3}$ & 1.6 & 1.7 & 1.84 & 1.77 & 0.946 & 15.9 \\
\hline Live weight (grams) & 2380 & 2340 & 2420 & 2470 & 0.997 & 40.9 \\
\hline Mortality & 0.000 & 0.333 & 0.000 & 0.333 & 0.588 & 27.3 \\
\hline Growth rate (grams) & 87 & 89 & 81 & 80 & 0.401 & 51.9 \\
\hline
\end{tabular}

\section{Feet health}

The influence of litter material on broiler feet health results are shown in Table 2. Litter material treatments had a significant influence $(P \leq 0.05)$ on footpad dermatitis while hock burn and broiler body temperature were not statistically $(P \geq 0.05)$ different amongst the litter treatments. The highest incidences of footpad dermatitis were found in sand, followed by dry pine tree leaves while decomposed kraal manure had the lowest incidences. Hock burns results on the other hand were highest in pine tree leaves and sand while decomposed kraal manure had no incidences of hockburns. The findings of the current study are in agreement with the findings of Mendes et al. (2013) who compared wood shaving and saw dust litter materials and observed significant differences between two sources whereby wood shavings had 
higher incidences than saw dust. Garcia et al. (2012) also reported that birds raised on litter made of $100 \%$ wood shaving had no incidences of footpad dermatitis. Hock burn results are in line with the results of Varol Avcilar et al. (2018) that compared wood shavings and rice hulls and reported that were no significant difference in hock burns between two litter sources.

On the other hand, Bilgili et al. (2009), observed highest incidences of footpad dermatitis in wood shavings and dry pine tree leaves, while mortar sand was ranked as the bedding material with the lowest severity. Lacy et al. (2002) discovered that a problem with dry pine tree leaves is breast blisters and greater incidence of hock burns during the first two weeks. Bilgili et al. (2000) and Chuppava et al. (2018) reported contrasting results and indicated that broilers raised on sand performed as well as or better than those raised on pine shavings and it had the lowest incidences and severity of hock burns and other skin lesions. Body temperatures of birds reared in wood shavings, which was the control, were increasing gradually across the weeks while those reared in sand showed the least body temperatures of all litter materials. These findings are in agreement with the report of Gernat (2009) stating that sand had the lowest temperatures resulting in low body temperatures of the birds but that did not have a negative impact on productivity. Decomposed kraal manure in terms of feet health gave similar performance to wood shavings and could be a potential litter that can be used to improve broiler feet health.

\section{Table 2 - The effects of litter material on birds feet health}

\begin{tabular}{|c|c|c|c|c|c|c|}
\hline \multirow{2}{*}{ Parameters } & \multicolumn{4}{|c|}{ Litter treatments } & \multicolumn{2}{|c|}{ Significance } \\
\hline & Control & T1 (DPL) & T2 (DKM) & T3 (SAND) & $\mathbf{P} 1$ & $\mathrm{CV}^{2}$ \\
\hline Incidence of FPD ${ }^{3}(\%)$ & $0.00^{a}$ & $16.25^{b}$ & $9.85^{a}$ & $64.25^{c}$ & 0.01 & 13.73 \\
\hline Body temperature $\left({ }^{\circ} \mathrm{C}\right)$ & 40.75 & 40.93 & 40.76 & 40.46 & 0.46 & 0.33 \\
\hline Hock burns & 2.50 & 8.25 & 0.00 & 4.00 & 0.12 & 15.5 \\
\hline
\end{tabular}

\section{Physical and chemical evaluation}

The comparison of physical and chemical properties of different litter materials results are shown in table 3. According to these results there were significant differences among different litter treatments in physical and chemical properties with the exception of litter temperature. According to mean comparison test there was no significant difference between control, dry pine leaves and sand in terms of ammonia emission. In terms of water holding capacity, there was no significant difference between the control and dry pine leaves. With regard to litter pH, there was no significant difference between control, dry pine leaves and decomposed kraal manure. Lastly mean comparison test result shows that there was no significant difference between wood shavings and decomposed kraal manure in terms of bulk density.

These results are in agreement with the findings of Brake et al. (1993) and Kuczynski and Slobodzian (2002) who noticed that there were no a significant difference $(P \geq 0.005)$ in physical and chemical properties between different litter sources while comparing wood shavings with wheat straw, rice straw and sand. Farhadi (2014) used both wood shavings and saw dust as control in the study that seeks to find a potential litter material for broiler and compared them to wheat straw, sugarcane bagasse, sugarcane peat; rice hulls and the researcher found no significant difference between control and the tested litter materials in terms of moisture content, $\mathrm{pH}$, water holding and water releasing capacity and bulk density. Ammonia emission results pointed out the use of kraal manure as litter material should be handled with extra care especially if the substrate is not fully decomposed. Ammonia emissions in this study were higher than the recommended threshold value of $25 \mathrm{ppm}$ for broiler house. The higher values could be associated with poor level of litter decomposition prior to its use as litter material. The higher bulk density also could have contributed significantly because lower bulk density of a material shows high porosity and moisture absorbing capacity, air circulating and moisture releasing capacity than high bulk density (Ataputta and Wickramasinghe, 2007). Litter pH was similar between dried pine leaves and decomposed kraal but they were significantly higher than the control. It was reported that the low $\mathrm{pH}$ level of litter material has an advantage because in acidic $\mathrm{pH}$ of litter, the conversion of uric acid to ammonia will be reduced (Moore et al., 1996). The lower litter temperature observed under sand could be a contributing factor for higher feed intake for birds under this treatment in an effort to maintain high metabolic activities to keep warm.

Table 3 - Physical and chemical properties of different litter materials

\begin{tabular}{|c|c|c|c|c|c|c|}
\hline \multirow{2}{*}{ Parameters } & \multicolumn{4}{|c|}{ Litter treatments } & \multicolumn{2}{|c|}{ Significance } \\
\hline & Control & T1 (DPL) & T2 (DKM) & T3 (SAND) & $\mathbf{P} 1$ & $\mathrm{CV}^{2}$ \\
\hline Ammonia emissions ( $\mathrm{mg} / \mathrm{L})$ & $6.93^{a}$ & $19.50^{a}$ & $27.29^{b}$ & $17.25^{a}$ & 0.001 & 42.00 \\
\hline Water holding (\%) & $114.95^{a}$ & $105.81^{a}$ & $92.20^{\mathrm{b}}$ & $56.94^{c}$ & 0.001 & 25.00 \\
\hline Litter temperature & 17.35 & 17.96 & 17.84 & 16.90 & 0.681 & 7.36 \\
\hline pH & $6.18^{a}$ & $6.73^{b}$ & $6.75^{b}$ & $7.36^{c}$ & 0.001 & 10.00 \\
\hline Bulk density (g/cm³) & $300.14^{a}$ & $205.06^{b}$ & $370.50^{a}$ & $1788.75^{c}$ & 0.001 & 101.00 \\
\hline
\end{tabular}


In accordance with the findings of the current study, separated into production, feet health and chemical and physical assessment, it can be concluded that both dried pine leaves and decomposed kraal manure can be used as broiler litter material. Kraal manure had been found to be a good source that can support proper feed health with the lowest incidence of feet pad dermatitis and hock burns. Dried pine tree leaves proved to be a good source that can maintain production in the similar manner to wood shavings. The use of kraal manure needs full decomposition in order to reduce the incidences of ammonia emissions. The two litter sources are therefore recommended for farmers who want to use them because they are readily available in Lesotho.

\section{DECLARATIONS}

\section{Corresponding Author}

E-mail: nchelekuleile@gmail.com

\section{Author's contribution}

N.Kuleile participated in the design of the study. Metsing and M.Phororo collected the litter materials, constructed the pens and tested the litters on broilers. I.Metsing, M.Phororo, T.Jobo, and C.Tjala performed the experiments and analyzed the data. N.Kuleile critically revised the manuscript for important intellectual contents and wrote the manuscript. All authors read and approved the final manuscript.

\section{Competing interests}

The authors declare that they have no competing interests.

\section{REFERENCES}

Anonymous (1990). General note on stock management (litter management). Poultry Management Guide, pp. 4-5.

Asaniyan K, Agbede $O$ and Laseinde $O$ (2007).Impact assessment of different litter depths on the performance of broiler chickens raised on sand and wood shaving litters. WJZ, 2(2): 67-72. Google Scholar

Brake D, Fuller J, Boyle R, Link E, Peebles D and Latour A (1993). Evaluations of whole chopped kenaf and kenaf core used as a broiler litter material. Poultry Science. 72(11): 2079-2083. Google Scholar

Bjedov S, Žikić D, Perić L, Đukić Stojčić M and Milošević N (2013). Effect of different litter treatments on production performance of broiler chickens. Biotechnology in Animal Husbandry 29(4): 625-630. Google Scholar I http://doi.org/10.2298/BAH1304625BM

Bilgili S, Hess J, Blake J, Eckman M (2000). Turning trash into treasure: Sand as bedding material for rearing broilers. Highlights of Agricultural Research. 47 (1). http://www.ag.auburnedu/aaes/information/highlights/spring00/sand.html I Google Scholar

Bilgili F, Montenegro I, Hess B and Eckman K (2009). Live performance, carcass quality, and deboning yields of broilers reared on sand as a litter source. Journal of Applied Poultry Research, 8(3): 352-361. Google Scholar

Chuppava B, Visscher C and Kamphues J (2018). Effect of different flooring designs on the performance and foot pad health in broilers and turkeys. Animals Basel, 8(5):70. http://doi.org/10.3390/ani8050070

Davis D, Purswell L, Columbus P and Kiess S (2010). Evaluation of chopped switch grass as a litter material. International Journal of Poultry Science, 9(1): 39-42. Google Scholar

Dunlop W, McAuley J, Blackall J and Stuetz M (2016). Water activity of poultry litter: Relationship to moisture content during a grow-out. Journal of Environmental Management, 172: 210-201. Google Scholar I http://dx.doi.org/10.1016/j.jenvman.2016.02.036

Toghyani M, Gheisari A, Modaresi M, Tabeidian SA, Toghyani M (2010). Effect of different litter material on performance and behavior of broiler chickens. Applied Animal Behaviour Science, 122(1), 48-52. Google Scholar

García RG, Almeida Paz ICL, Caldara FR, Nääs IA, Pereira DF and Ferreira VMOS (2012). Selecting the most adequate bedding material for broiler production. Brazil Journal of Poultry Science, 14(2): 121-127. Google Scholar

Gernat A (2009). Use of sand as litter for broilers. https://www.wattagnet.com/articles/3911-use-of-sand-as-asbroiler.litter

Gençoğlan S and Gençoğlan C (2017). The effect of the litter materials on broiler chickens welfare and performance. Turkish Journal of Agriculture, Food Science and technology. 5(12): 1660-1667. https://doi.org/10.24925/turjaf.v5i12.1660-1667.176

Hafeez A, Suhail M, Durrani R, Jan D, Ahmad I and Rehman A (2009). Effect of different types of locally available litter materials on the performance of broiler chicks. Sarhad Journal Agriculture. 25(4): 581-586

Haslam S, Knowles G,Brown N, Wilkins L and Kestin C (2007). Factors affecting the prevalence of foot pad dermatitis, hock burn and breast burn in broiler chicken. British Poultry Science, 48 (03):264-275. http://dx.doi.org/10.1080/00071660701371341

Hossain A, Zulkifili I, Islam S and Awad A (2018). Effect of wood shaving litter density on the growth, leg disorders and manurial value in broiler. Bangladesh Journal of Animal Science. 47(1): 21-27. Google Scholar

Kuczynski T and Slobodzian 0 (2002). Physical properties of different types of litter and their effect on animal health and welfare in turkey housing. Annuals of Animal Science, 1: 31-33. Google Scholar I Link 
Kryeziu J, Mestani N, Berisha H and Kamberi A (2018). The European performance indicators of broiler chickens as influenced by stocking density and sex. Agronomy Research 16(2): 483-491. https://doi.org/10.15159/AR.18.040

Lacy P (2002). Litter quality and broiler performance. The University of Georgia College of Agricultural \& Environmental Sciences. Cooperative Extension Service. http://www.ces.uga.edu/pubcd/L426-w.html

Lonkar D,Ranade S, Kulkarni R, Pathak B, Yenge D and Daware G (2018). Effect of organic acid treated corn cob bedding material on broiler performance, hock burn incidence and litter quality. International Journal of Science, Environment and Technology, 7(2): 397-409. ISSN: 2278-3687. Google Scholar

Mendes S, Paixão J, Restelatto R, Reffatti R, Possenti C, Moura DJ, Morello Z and Carvalho R (2011). Effects of initial body weight and litter material on broiler production. Brazilian Journal of Poultry Science 13(3):165-170. Google Scholar I https://doi.org/10.1590/S1516-635X2011000300001

Munir MT, Belloncle C, Irle M and Federighi M (2019). Wood-based litter in poultry production: a review. Worlds Poultry Science Journal, https://doi.org/10.1017/S0043933918000909

Musilova A, Lichovnikova M and Przywarova A (2014). The effect of the type of litter on the occurrence of footpad dermatitis in broiler chickens. Mendel Net. pp 167-171. Google Scholar

Ritz CW, Fairchild BD and Lacy MP (2017). Litter Quality and Broiler Performance. University of Georgia, College of Agricultural and Environmental Sciences. Extension Bulletin. No 1267. Google Scholar

Ritz CW, Fairchild BD, Lacy MP (2009). Litter quality and broiler performance. University of Georgia. College of Agricultural and Environmental Sciences. Link

Shepherd EM, Fairchild BD, and Ritz CW (2017). Alternative bedding materials and litter depth impact litter moisture and footpad dermatitis. Journal of Applied Poultry Research. 26: 518-528. Google Scholar I http://dx.doi.org/10.3382/japr/pfx024

Taherparvar G, Seidavi A, Asadpour L, Rita Payan-Carreira R,Laudadio V and-Tufarelli V (2016). Effect of litter treatment on growth performance, intestinal development, and selected cecum microbiota in broiler chickens. Revista Brasileira de Zootecnia, 45(5): 257-264. Google Scholar

Van Harn J, Aarnink J, Mosquera J, van Riel W and Ogink M (2012). Effect of bedding material on dust and ammonia emission from broiler houses. American Society of Agricultural and Biological Engineers, 55(1):219-226. http://dx.doi.org/10.13031/2013.41249

Varol Avcilar Ö, Kocakaya A, Onbasilar E and Pirpanahi M (2018). Influence of sepiolite additions to different litter materials on performance and some welfare parameters of broilers and litter characteristics. Poultry Science Journal, 97(9):3085-3091. http://dx.doi.org/10.3382/ps/pey185

Villagra A, Olivas I, Benitez V and Lainez M (2011): Evaluation of sludge from paper recycling as bedding material for broilers. Poultry Science, 90(5): 953-957. Google Scholar I https://doi.org/10.3382/ps.2010-00935

Waziri I and Kaltungo Y (2017). Poultry litter selection, management and utilization inthe tropics. In Poultry Science web book. Chapter 8: pp 192-208. Google Scholar I http://dx.doi.org/10.5772/65036

World Organisation for Animal Health (2018). Animal welfare and broiler chicken production, chapter 7.10. In; Terrestrial Animal Health code-10/08/2018. Pp. 2. 